\title{
IgE-mediated cow's milk allergy in patients under 2 years of age, suffering from $A D$
}

\author{
Nino Lomidze ${ }^{1 *}$, Maia Gotua', Tamar Gotua² \\ From Food Allergy and Anaphylaxis Meeting 2011 \\ Venice, Italy. 17-19 February 2011
}

\section{Background}

Food allergy affects $6-8 \%$ of children before the age of 5 and is a frequent cause of many allergic diseases. Sensitization in infancy predominantly occurs first to cow's milk and egg white. It is estimated that 2 to $5 \%$ of infants develop milk allergy. Food allergy is a known provoking cause of Atopic Dermatitis (AD) in a subset of affected children and triggers skin symptoms in about $30 \%$ of children. The aim of our study was to evaluate the role of sensitization to cow's milk under 2 years of age with $\mathrm{AD}$ in Georgian population.

\section{Method}

121 patients under 2 years of age with AD (male-60, female-61) were investigated. Analyzed data included clinical history, Severity Scoring of Atopic Dermatitis Index (SCORAD), measurements of total serum IgE and specific IgE to food allergens was tested by CAP System_fluorescent enzyme immunoassay (ImmunoCap, Phadia). Specific IgE level $\geq 0.35 \mathrm{kUA} / \mathrm{l}$ was considered as positive.

\section{Results}

Specific IgE to cow's milk was positive in $33.9 \%$ of cases. Among them the high level of allergen specific IgE to cow's milk (RAST classes $4-5$ ) revealed in $2.4 \%$ of patients with atopic dermatitis, moderate level (3 class) $4.9 \%$, low level (1-2 classes) - $27.3 \%$. Increased value of total IgE was detected in $45.4 \%$ of studied children. In some patients suspected having allergy to other food allergens, specific IgE to casein (29 investigated cases), to flour mixture - wheat, oat, maize, sesame, seed, buckwheat (32 cases), and to hen's egg (30 cases) were measured. Co-sensitization with milk was revealed in $20.7 \%$ of casein studied cases, $15.6 \%$ of flour mixture and

${ }^{1}$ Center of Allergy \& Immunology, Tbilisi, Georgia

Full list of author information is available at the end of the article
$26.6 \%$ of hen's egg positive cases. $0.8 \%$ of infants with atopic dermatitis showed positive results to cow's milk, hen's egg and flour mixture. The degree of sensitization was correlating with SCORAD.

\section{Conclusion}

Our study demonstrates that $33,9 \%$ of children under 2 years of age with AD in Georgia is sensitized to milk allergen, that should be considered for early induction of proper dietary, treatment and preventive measures. Further investigations are strongly recommended.

\section{Author details}

${ }^{1}$ Center of Allergy \& Immunology, Tbilisi, Georgia. ${ }^{2}$ Jvania's Children Hospital, Tbilisi, Georgia.

Published: 12 August 2011

doi:10.1186/2045-7022-1-S1-P74

Cite this article as: Lomidze et al.: IgE-mediated cow's milk allergy in patients under 2 years of age, suffering from AD. Clinical and Translational Allergy 2011 1(Suppl 1):P74.

Submit your next manuscript to BioMed Central and take full advantage of:

- Convenient online submission

- Thorough peer review

- No space constraints or color figure charges

- Immediate publication on acceptance

- Inclusion in PubMed, CAS, Scopus and Google Scholar

- Research which is freely available for redistribution

\section{Biomed Central}

